\title{
Overlapping genetic susceptibility variants between three autoimmune disorders: rheumatoid arthritis, type 1 diabetes and coeliac disease
}

\author{
Stephen Eyre ${ }^{1 *}$, Anne Hinks ${ }^{1}$, John Bowes ${ }^{1}$, Edward Flynn' ${ }^{1}$ Paul Martin ${ }^{1}$, Anthony G Wilson², Ann W Morgan ${ }^{3}$, \\ Paul Emery ${ }^{3}$, Sophia Steer ${ }^{4}$, Lynne J Hocking ${ }^{5}$, David M Reid ${ }^{5}$, Pille Harrison ${ }^{6}$, Paul Wordsworth ${ }^{6}$, \\ Yorkshire Early Arthritis (YEAR) Consortium, Biologics in RA Control (BIRAC) Consortium, Wendy Thomson', \\ Jane Worthington ${ }^{1}$, Anne Barton ${ }^{1}$
}

\begin{abstract}
Introduction: Genome wide association studies, replicated by numerous well powered validation studies, have revealed a large number of loci likely to play a role in susceptibility to many multifactorial diseases. It is now well established that some of these loci are shared between diseases with similar aetiology. For example, a number of autoimmune diseases have been associated with variants in the PTPN22, TNFAIP3 and CTLA4 genes. Here we have attempted to define overlapping genetic variants between rheumatoid arthritis (RA), type 1 diabetes (T1D) and coeliac disease (CeD).
\end{abstract}

Methods: We selected eight SNPs previously identified as being associated with CeD and six T1D-associated SNPs for validation in a sample of 3,962 RA patients and 3,531 controls. Genotyping was performed using the Sequenom MassArray platform and comparison of genotype and allele frequencies between cases and controls was undertaken. A trend test $P$-value $<0.004$ was regarded as significant.

Results: We found statistically significant evidence for association of the TAGAP locus with RA $\left(P=5.0 \times 10^{-4}\right)$. A marker at one other locus, C1QTNF6, previously associated with T1D, showed nominal association with RA in the current study but did not remain statistically significant at the corrected threshold.

Conclusions: In exploring the overlap between T1D, CeD and RA, there is strong evidence that variation within the TAGAP gene is associated with all three autoimmune diseases. Interestingly a number of loci appear to be specific to one of the three diseases currently studied suggesting that they may play a role in determining the particular autoimmune phenotype at presentation.

\section{Introduction}

Rheumatoid arthritis (RA) is an auto-immune, inflammatory joint condition, affecting $0.8 \%$ of the UK population [1]. It has long been established that the major genetic predisposition to this disease is contributed by variants of the class II HLA gene, HLA DRB1. Both type 1 diabetes (T1D) and coeliac disease (CeD) are also

\footnotetext{
* Correspondence: steve.eyre@manchester.ac.uk

'Arthritis Research UK-Epidemiology Unit, Stopford Building, Oxford Road,

The University of Manchester, Manchester M13 9PT, UK

Full list of author information is available at the end of the article
}

auto-immune, inflammatory diseases for which the major genetic contribution arises from the major histocompatibility complex and which are also characterised by autoantibody formation [2].

Recent genome wide association and subsequent replication studies in these three diseases have revealed a large number of well validated, non-HLA genetic risk loci providing an opportunity to explore the possibility of overlapping susceptibility between them [3]. Testing confirmed T1D susceptibility loci in CeD samples has already resulted in the identification of novel CeD loci [2]. 
A previous study exploring the overlap of $\mathrm{CeD}$ and $\mathrm{RA}$ susceptibility loci identified association to six regions [4]. We have recently reported our findings of the testing of putative T1D susceptibility loci in RA, which identified $A F F 3$ as a novel RA susceptibility locus [5]. However, exploring the overlap between the three diseases in more detail may provide a further opportunity to elucidate the genetic similarities, and differences, between these common autoimmune diseases.

We, therefore, tested 14 validated susceptibility loci from CeD and T1D in a large, well powered cohort of British Caucasian patients with RA and independent controls to explore the overlap between loci identified in all three conditions.

\section{Materials and methods Samples}

Clinical characteristics of the RA case-control cohort tested have been described previously [6]. RA cases satisfied American College of Rheumatology (ACR) classification criteria for RA modified for genetic studies, all provided informed consent and were collected with ethical committee approval (North-West Multi-Centre Research Ethics Committee (MREC 99/8/84) and the University of Manchester Committee on the Ethics of Research on Human Beings) $[7,8]$. Their clinical characteristics are shown in Table S1 in Additional file 1.

\section{SNP selection}

SNP markers with evidence for association with $\mathrm{CeD}$ susceptibility $\left(P<1 \times 10^{-5}\right)$ in reference [2] were selected for genotyping in a cohort of RA and control samples. Where more than one SNP was associated at a particular locus with $\mathrm{CeD}$, the most associated variant was selected for genotyping in the RA case-control cohort.

SNP markers with evidence for association in T1D in the same reference, but not genotyped as part of our previous work, were also selected for genotyping in the current cohort of RA cases and controls.

\section{Genotyping}

SNP markers were genotyped using the iPlex chemistry on the Sequenom platform according to the manufacturer's instructions (Sequenom, San Diego, California, USA) [9]. Duplicate samples and negative controls were included on the plates to ensure genotyping accuracy. Additional quality control measures were introduced such that only SNP markers and samples exceeding a $90 \%$ genotyping success threshold were included in any subsequent analysis.

\section{Analysis}

The power to detect association in the current cohort assuming the same odds ratio (OR) as was reported in the $\mathrm{CeD}$ disease study was calculated using Quanto [10]. Departure from Hardy-Weinberg equilibrium was tested for all SNP markers. Genotype frequencies were compared between RA cases and controls using the trend test implemented in STATA (StataCorp LP, Texas, USA). Conditional logistic regression was used to assess whether effects were independent where two SNPs had been tested at the same locus.

\section{Results}

\section{SNP selection}

Eight CeD SNPs were selected for genotyping as they had not previously been examined for association with RA (Table 1). We have previously reported our results for most but not all of the T1D loci tested in a recent study exploring the genetic overlap between $\mathrm{CeD}$ and T1D [5]. For completeness, six T1D associated SNPs not previously investigated for association with RA in the current data set were, therefore, also tested (Table 2).

\section{Genotyping}

Genotyping was undertaken in an available validation cohort of 3,962 RA cases and 3,531 controls from the UK. A $P$-value of 0.004 was selected as the nominal significance threshold. The study had between $67 \%$ and 99\% power to detect association with the CeD loci in this sample at the $P<0.004$ threshold assuming the same allele frequencies and effect sizes as reported with CeD (Table S2 in Additional file 1). Duplicate samples showed $>99 \%$ concordance. All samples and SNPs met the quality control threshold of $>90 \%$ genotyping success. All SNP genotype frequencies conformed to Hardy-Weinberg expectations in the controls.

One marker with previous evidence for association with $\mathrm{CeD}$ was also associated with RA in the current cohort: rs182429 mapping to the TAGAP gene OR 0.88 , 95\% confidence intervals (CI) 0.82 to 0.95 ; $P$-trend 0.0005) (Table 1). The TAGAP locus has previously been identified as an RA susceptibility locus following meta-analysis of genome-wide association studies in RA followed by validation in independent samples, which included samples from the current study [11]. However, a different SNP marker (rs394581) was tested in that study. The two SNPs were in moderate linkage disequilibrium (LD) $\left(r^{2}=0.32\right.$; $\left.D^{\prime}=0.73\right)$ in the control samples tested here but conditional logistic regression analysis suggested that the association arises primarily from the CeD SNP, rs182429 ( $P$-value for rs394581 after conditioning on rs182429 $=0.90$ ).

Of the T1D SNPs tested, only rs229541, mapping to C1QTNF6, showed nominal evidence for association but this did not retain statistical significance at the threshold selected (OR 1.08, 95\% CI 1.0 to $1.15, P=0.04)$ (Table 2). 
Table 1 Results of association testing of previously reported CeD-associated loci with RA susceptibility

\begin{tabular}{|c|c|c|c|c|c|c|c|c|c|c|c|c|c|c|}
\hline SNP & CHR & position & Gene & MAF cases & MAF controls & P_HWE & case_11 & case_12 & case_22 & control_11 & control_12 & control_22 & P_trend & Allelic OR $(95 \% \mathrm{Cl})$ \\
\hline rs2816316 & 1 & 190803436 & RGS1 & 0.17 & 0.18 & 0.31 & $\begin{array}{l}119 \\
(3.3)\end{array}$ & $\begin{array}{l}1027 \\
(28.2)\end{array}$ & $\begin{array}{l}2501 \\
(68.6)\end{array}$ & $\begin{array}{l}99 \\
(3.4)\end{array}$ & $\begin{array}{l}835 \\
(28.5)\end{array}$ & $\begin{array}{l}1993 \\
(68.1)\end{array}$ & 0.65 & $\begin{array}{l}0.98 \\
(0.89 \text { to } 1.07)\end{array}$ \\
\hline rs917997 & 2 & 102437000 & ILIBRAP & 0.23 & 0.22 & 0.87 & $\begin{array}{l}208 \\
(5.7)\end{array}$ & $\begin{array}{l}1,285 \\
(35.2)\end{array}$ & $\begin{array}{l}2,154 \\
(59.1)\end{array}$ & $\begin{array}{l}147 \\
(5.0)\end{array}$ & $\begin{array}{l}1,013 \\
(34.6)\end{array}$ & $\begin{array}{l}1,771 \\
(60.4)\end{array}$ & 0.17 & $\begin{array}{l}1.06 \\
(0.98 \text { to } 1.15)\end{array}$ \\
\hline rs6441961 & 3 & 46327388 & CCR3 & 0.31 & 0.31 & 0.76 & $\begin{array}{l}350 \\
(9.6)\end{array}$ & $\begin{array}{l}1,582 \\
(43.3)\end{array}$ & $\begin{array}{l}1,720 \\
(47.1)\end{array}$ & $\begin{array}{l}280 \\
(9.6)\end{array}$ & $\begin{array}{l}1,239 \\
(42.3)\end{array}$ & $\begin{array}{l}1,409 \\
(48.1)\end{array}$ & 0.52 & $\begin{array}{l}1.03 \\
(0.95 \text { to } 1.1)\end{array}$ \\
\hline rs333 & 3 & 46389951 & CCR5 & 0.1 & 0.11 & 0.38 & $\begin{array}{l}23 \\
(0.7)\end{array}$ & $\begin{array}{l}689 \\
(19.6)\end{array}$ & $\begin{array}{l}2,802 \\
(79.7)\end{array}$ & $\begin{array}{l}35 \\
(1.1)\end{array}$ & $\begin{array}{l}642 \\
(20.6)\end{array}$ & $\begin{array}{l}2,444 \\
(78.3)\end{array}$ & 0.08 & $\begin{array}{l}0.91 \\
(0.81 \text { to } 1.01)\end{array}$ \\
\hline rs17810546 & 3 & 161147744 & IL12A & 0.12 & 0.12 & 0.66 & $\begin{array}{l}52 \\
(1.4)\end{array}$ & $\begin{array}{l}736 \\
(20.2)\end{array}$ & $\begin{array}{l}2,862 \\
(78.4)\end{array}$ & $\begin{array}{l}45 \\
(1.5)\end{array}$ & $\begin{array}{l}616 \\
(21.1)\end{array}$ & $\begin{array}{l}2,264 \\
(77.4)\end{array}$ & 0.32 & $\begin{array}{l}0.95 \\
(0.85 \text { to } 1.05)\end{array}$ \\
\hline rs1464510 & 3 & 189595248 & $\angle P P$ & 0.45 & 0.44 & 0.72 & $\begin{array}{l}697 \\
(19.9)\end{array}$ & $\begin{array}{l}1,730 \\
(49.4)\end{array}$ & $\begin{array}{l}1,077 \\
(30.7)\end{array}$ & $\begin{array}{l}617 \\
(19.9)\end{array}$ & $\begin{array}{l}1,524 \\
(49.1)\end{array}$ & $\begin{array}{l}966 \\
(31.1)\end{array}$ & 0.82 & $\begin{array}{l}1.01 \\
(0.94 \text { to } 1.08)\end{array}$ \\
\hline rs182429 & 6 & 159389562 & TAGAP & 0.42 & 0.45 & 0.82 & $\begin{array}{l}600 \\
(17.0)\end{array}$ & $\begin{array}{l}1,770 \\
(50.2)\end{array}$ & $\begin{array}{l}1,159 \\
(32.8)\end{array}$ & $\begin{array}{l}590 \\
(20.5)\end{array}$ & $\begin{array}{l}1,421 \\
(49.3)\end{array}$ & $\begin{array}{l}870 \\
(30.2)\end{array}$ & 0.0005 & $\begin{array}{l}0.88 \\
(0.82 \text { to } 0.95)\end{array}$ \\
\hline rs653178\# & 12 & 110492139 & $\mathrm{SH} 2 \mathrm{~B} 3$ & 0.49 & 0.51 & 0.68 & $\begin{array}{l}914 \\
(25.1)\end{array}$ & $\begin{array}{l}1,744 \\
(47.9)\end{array}$ & $\begin{array}{l}985 \\
(27.0)\end{array}$ & $\begin{array}{l}771 \\
(26.4)\end{array}$ & $\begin{array}{l}1,449 \\
(49.6)\end{array}$ & $\begin{array}{l}703 \\
(24.1)\end{array}$ & 0.02 & $\begin{array}{l}0.92 \\
(0.86 \text { to } 0.98)\end{array}$ \\
\hline
\end{tabular}

$\# r^{2}=1$ with rs3184504; 11 = homozygote for minor allele, 12 = heterozygote, $22=$ homozygote for major allele; CHR, chromosome; MAF, minor allele frequency; $\mathrm{P}$ HWE, $P$-value for Hardy Weinberg equilibrium test.

Table 2 Association testing of six T1D associated SNPs not previously investigated for association with RA in the current cohort

\begin{tabular}{|c|c|c|c|c|c|c|c|c|c|c|c|c|c|c|}
\hline$\overline{\text { SNP }}$ & CHR & position & Gene & MAF cases & MAF controls & P_HWE & case_11 & case_12 & case_22 & control_11 & control_12 & control_22 & P_trend & $\begin{array}{l}\text { Allelic OR } \\
(95 \% \mathrm{CI})\end{array}$ \\
\hline rs11755527 & 6 & 91014952 & $\mathrm{BACH} 2$ & 0.46 & 0.46 & 0.91 & $\begin{array}{l}729 \\
(20.8)\end{array}$ & $\begin{array}{l}1,790 \\
(51.0)\end{array}$ & $\begin{array}{l}990 \\
(28.2)\end{array}$ & $\begin{array}{l}669 \\
(21.5)\end{array}$ & $\begin{array}{l}1,551 \\
(49.9)\end{array}$ & $\begin{array}{l}891 \\
(28.6)\end{array}$ & 0.86 & $\begin{array}{l}0.99 \\
\text { (0.93 to } 1.06)\end{array}$ \\
\hline rs689 & 11 & 2138800 & INS & 0.28 & 0.28 & 0.54 & $\begin{array}{l}287 \\
(8.2)\end{array}$ & $\begin{array}{l}1,411 \\
(40.1)\end{array}$ & $\begin{array}{l}1,818 \\
(51.7)\end{array}$ & $\begin{array}{l}254 \\
(8.2)\end{array}$ & $\begin{array}{l}1,246 \\
(40.0)\end{array}$ & $\begin{array}{l}1,612 \\
(51.8)\end{array}$ & 0.95 & $\begin{array}{l}1.00 \\
\text { (0.93 to } 1.08)\end{array}$ \\
\hline rs12708716 & 16 & 11087374 & CLEC16A & 0.36 & 0.36 & 0.63 & $\begin{array}{l}507 \\
(12.9)\end{array}$ & $\begin{array}{l}1,791 \\
(45.4)\end{array}$ & $\begin{array}{l}1,643 \\
(41.7)\end{array}$ & $\begin{array}{l}453 \\
(12.9)\end{array}$ & $\begin{array}{l}1,596 \\
(45.5)\end{array}$ & $\begin{array}{l}1,455 \\
(41.5)\end{array}$ & 0.88 & $\begin{array}{l}1.00 \\
\text { (0.93 to } 1.06)\end{array}$ \\
\hline rs3825932 & 15 & 77022501 & CTSH & 0.32 & 0.32 & 0.77 & $\begin{array}{l}368 \\
(10.5)\end{array}$ & $\begin{array}{l}1,506 \\
(43.1)\end{array}$ & $\begin{array}{l}1,619 \\
(46.3)\end{array}$ & $\begin{array}{l}323 \\
(10.4)\end{array}$ & $\begin{array}{l}1,366 \\
(44.1)\end{array}$ & $\begin{array}{l}1,407 \\
(45.4)\end{array}$ & 0.62 & $\begin{array}{l}0.98 \\
\text { (0.91 to } 1.06)\end{array}$ \\
\hline rs3788013 & 21 & 42714397 & UBASH3A & 0.45 & 0.43 & 0.86 & $\begin{array}{l}705 \\
(20.1)\end{array}$ & $\begin{array}{l}1,752 \\
(49.9)\end{array}$ & $\begin{array}{l}1,052 \\
(30.0)\end{array}$ & $\begin{array}{l}590 \\
(19.0)\end{array}$ & $\begin{array}{l}1,522 \\
(49.0)\end{array}$ & $\begin{array}{l}996 \\
(32.0)\end{array}$ & 0.07 & $\begin{array}{l}1.07 \\
(1.00 \text { to } 1.14)\end{array}$ \\
\hline rs229541 & 22 & 35921264 & CIQTNF6 & 0.45 & 0.43 & 0.49 & $\begin{array}{l}726 \\
(20.6)\end{array}$ & $\begin{array}{l}1,693 \\
(48.1)\end{array}$ & $\begin{array}{l}1,100 \\
(31.3)\end{array}$ & $\begin{array}{l}564 \\
(18.1)\end{array}$ & $\begin{array}{l}1,548 \\
(49.6)\end{array}$ & $\begin{array}{l}1,007 \\
(32.3)\end{array}$ & 0.04 & $\begin{array}{l}1.08 \\
(1.00 \text { to } 1.15)\end{array}$ \\
\hline
\end{tabular}

11 = homozygote for minor allele, 12 = heterozygote, 22 = homozygote for major allele; CHR, chromosome; MAF, minor allele frequency; P_HWE, $P$-value for Hardy Weinberg equilibrium test. 
Interestingly, this gene lies close to the IL2RB gene, which has previously been associated with RA susceptibility [6]. The apparent lack of association detected with T1D susceptibility loci in our sample may result from limited power to detect the effect sizes reported with the larger T1D samples: for three of the six loci, there was $<40 \%$ power to detect association at the $P<$ 0.004 threshold (Additional file 1 Table S2). However, association with the INS, CLEC16A and CTSH loci can be excluded with more confidence.

The three autoimmune diseases examined in the current study are characterised by the presence of autoantibodies and, interestingly, the association of the TAGAP variant is stronger in the subgroup of RA patients with anti-cyclic citrullinated peptide (anti-CCP) antibodies ( $P$-trend $=0.0001$, allelic OR $0.8395 \%$ CI 0.75 to 0.91$)$, suggesting a possible role in control of B cell function.

\section{Discussion}

By investigating the genetic overlap of $\mathrm{CeD}$ genes with RA, we have identified the TAGAP locus as being associated with RA. Our findings confirm and refine the results of a previous study in RA that also showed association to the TAGAP region but with a different variant; our results show that the same SNP that is associated with $\mathrm{CeD}$ and T1D also shows stronger evidence for association with RA [11]. Data from the current study extend that of previous work identifying that CTLA-4, the IL2_21 region, 6q23 (TNFAIP3), SH2B3, PRKCQ, MMEL1 and now TAGAP are susceptibility loci that are common to the three autoimmune diseases examined in the current study: T1D, CeD and RA $[2,5]$.

The current study is limited by the fact that, because the identification of novel susceptibility markers is progressing rapidly, a number of additional $\mathrm{CeD}$ and T1D susceptibility loci have been identified more recently, which have not been tested as yet for association with RA [12-14]. Hence, this is not a comprehensive examination of the overlap among all T1D, CeD and RA loci. However, of the loci tested so far, there appears to be greater overlap between T1D/CeD and T1D/RA than between $\mathrm{CeD}$ and RA. This may reflect the fact that larger sample sizes were used to investigate T1D (>8,000 T1D cases vs $>9,000$ controls) than $\mathrm{CeD}(2,500$ cases vs $>9,000$ controls), thereby reducing the possibility of false negative results in the T1D series. The lack of association of some of the CeD loci with RA could reflect lack of power, particularly if winner's curse has resulted in an overestimation of the effect sizes originally reported in the CeD studies. However, effect sizes observed when data from four GWAS of CeD were combined by meta-analysis were similar to those reported in the study by Smyth et al., which was used to select the $\mathrm{CeD}$ variants for testing in the current study $[2,13]$. That suggests that winner's curse and over-estimation of effects sizes in $\mathrm{CeD}$ cannot explain the lack of association observed with RA.

The TAGAP minor allele confers protection against RA, similar to previous reports of T1D but contrasting with $\mathrm{CeD}$ in which the minor allele is associated with risk. Our results confirm and extend the evidence that there are common autoimmune susceptibility genes but suggest that the overlap of RA is stronger with TID than CeD.

Relatively little is known about the TAGAP gene, which encodes a protein ( $\mathrm{T}$-cell activation RhoGTPase activating protein) transiently expressed in activated $\mathrm{T}$ cells, suggesting that it may have a role in immune regulation [2].

The TAGAP gene has previously been associated with RA following meta-analysis of US and European RA cohorts, although a different variant mapping to the same locus was genotyped [11]. Nonetheless, the same UK samples tested as part of the current study were also included in the validation phase of the meta-analysis and so data for both variants was available. The results of conditional logistic regression analysis suggest that the primary effect is with the CeD variant tested in the current study and that the association reported previously with rs394581, may have arisen due to $L D$, at least in the UK samples.

It is interesting to note that the SNP tested at the CCR5 locus which is associated with both T1D and CeD, also showed a trend towards association with RA. A previous meta-analysis of studies in RA investigating this deletion variant within the gene is suggestive of association with RA [15]. A combined meta-analysis, including data from the previous meta-analysis, two subsequent reports [16] and the current data, reveals statistically significant evidence for association $\left(P=1.4 \times 10^{-5}\right)$ but because of heterogeneity between the studies, these results should be interpreted with caution (Figure 1).

Exploring the genetic overlap between related diseases may reveal key common pathways that could suggest therapeutic targets applicable to more than one disease. However, the susceptibility loci unique to a particular disease are also of interest; differences may reflect genuine specificity between the diseases and may influence what determines the particular autoimmune phenotype. Of the confirmed non-HLA RA susceptibility loci (reviewed in [17]), only the CD40 and TRAF1/C5 variants have not been reported to be associated with either $\mathrm{CeD}$ or T1D although $C D 40$ is associated with autoimmune thyroiditis [18]. Even the TRAF1/C5 association is not unique to RA as there have been reports of association with juvenile idiopathic arthritis and systemic lupus erythematosus $[19,20]$. Despite the inherent bias arising from the fact that loci associated with one autoimmune disease are often subsequently targeted for investigation in other autoimmune diseases, the degree of genetic 


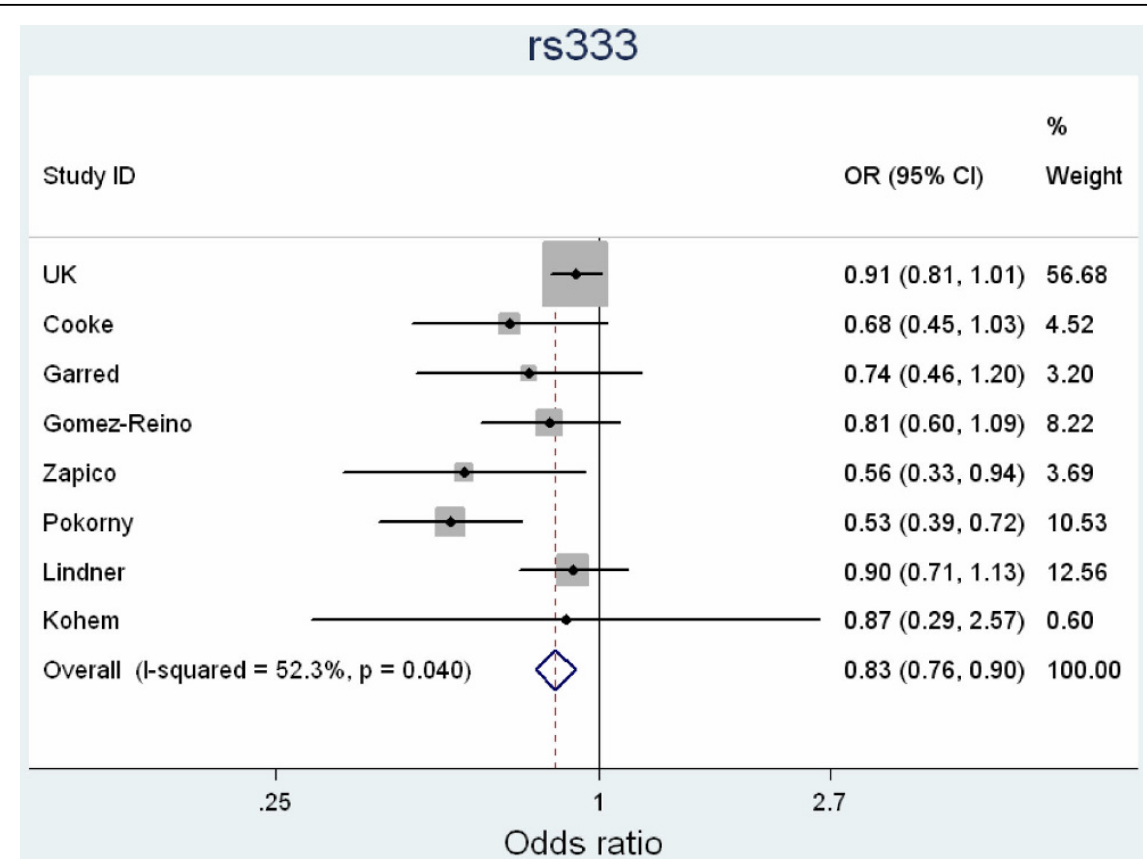

Figure 1 Meta-analysis of studies investigating a deletion in the CCR5 gene with RA susceptibility.

overlap is remarkable. One possible explanation may be that specificity of the autoimmune phenotype is determined by the particular HLA associations of each disease that could either directly or indirectly influence the response to environmental agents. This hypothesis would require further investigation in well-powered cohorts with both genetic and reliable environmental data.

In summary, we report association of RA with the TAGAP gene, identified through targeting loci previously associated with $\mathrm{CeD}$. The findings identify that the same SNP associated with T1D and CeD shows stronger association with RA than a previously reported variant and extend the evidence for overlap between autoimmunity genes.

\section{Conclusions}

The TAGAP gene, previously associated with both T1D and $\mathrm{CeD}$, is also associated with RA susceptibility. This confirms the finding of a previous study showing association of the TAGAP locus with RA but suggests that the variant associated with autoimmune diseases is more strongly associated than that reported previously.

\section{Additional material}

Additional file 1: Overlapping genetic susceptibility variants between three autoimmune disorders - supplementary information. The file

contains tables showing the clinical characteristics of the RA patient samples tested as well as the power of the study for each SNP tested.

\section{Abbreviations}

AFF3: AF4/FMR2 family member 3; C1QTNF6: C1q and tumour necrosis factor related protein 6; CCR5: cytokine-chemokine receptor 5; CD40: CD40 molecule; CED: coeliac disease; CHR: chromosome; Cl: confidence interval; CLEC16A: C-type lectin domain family 16; CTLA4: cytotoxic T lymphocyte activated 4; CTSH: cathepsin H; HLA: human leucocyte antigen; HWE: Hardy Weinberg equilibrium; IL: interleukin; IL2RB: interleukin 2 receptor beta; INS: insulin;LD: linkage disequilibrium; MAF: minor allele frequency; OR: odds ratio; PTPN22: protein tyrosine phosphatise non-receptor 22; RA: rheumatoid arthritis; SNP: single nucleotide polymorphism; T1D: type 1 diabetes; TAGAP: T-cell activation RhoGTPase activating protein; TNFAIP3: tumour necrosis factor activation induced protein 3; TRAF1/C5: tumour necrosis receptor activation factor 5/Complement 5; WTCCC: Wellcome Trust Case Control Consortium.

\section{Acknowledgements}

We thank Arthritis Research UK for their support (grant reference no: 17552). We are also grateful to the NIHR Manchester Biomedical Research Centre for support. Pille Harrison was funded from a departmental grant from the

Nuffield Dept of Orthopaedics, Rheumatology and Musculoskeletal Sciences, University of Oxford.

A full list of members for the YEAR and BIRAC consortiums can be found in Additional file 1 .

\section{Author details}

${ }^{1}$ Arthritis Research UK-Epidemiology Unit, Stopford Building, Oxford Road, The University of Manchester, Manchester M13 9PT, UK. ${ }^{2}$ School of Medicine \& Biomedical Sciences, Sheffield University, Beech Hill Road, Sheffield S10 2JF, UK. ${ }^{3} \mathrm{NIHR}$-Leeds Musculoskeletal Biomedical Research Unit, Leeds Institute of Molecular Medicine, University of Leeds, Beckett Street, Leeds LS2 9JT, UK. ${ }^{4}$ Clinical and Academic Rheumatology, Kings College Hospital NHS Foundation Trust, Denmark Hill, London SE5 9RS, UK. ${ }^{5}$ Musculoskeletal and Genetics Section, Division of Applied Medicine, University of Aberdeen, Foresterhill, Aberdeen AB25 2ZD, UK. ${ }^{6}$ University of Oxford Institute of Musculoskeletal Sciences, Botnar Research Centre, Windmill Road, Oxford OX3 7LD, UK.

\section{Authors' contributions}

$S E, W T$, JW and $A B$ conceived the study. EF and PM performed the genotyping, while $\mathrm{AH}$ and JB undertook the statistical analysis. YEAR and 
BIRAC consortia, AGW, AWM, PE, SS, LJH, DMR, PH, PW, JW and AB provided samples. SE and $A B$ drafted the manuscript, and all authors contributed to and approved the final version.

\section{Competing interests}

The authors declare that they have no competing interests.

Received: 21 May 2010 Revised: 10 August 2010

Accepted: 20 September 2010 Published: 20 September 2010

\section{References}

1. Symmons $D$, Turner $G$, Webb R, Asten P, Barrett E, Lunt M, Scott D, Silman A: The prevalence of rheumatoid arthritis in the United Kingdom: new estimates for a new century. Rheumatology (Oxford) 2002, 41:793-800.

2. Smyth DJ, Plagnol V, Walker NM, Cooper JD, Downes K, Yang JH, Howson JM, Stevens H, McManus R, Wijmenga C, Heap GA, Dubois PC, Clayton DG, Hunt KA, van Heel DA, Todd JA: Shared and distinct genetic variants in type 1 diabetes and celiac disease. N Engl J Med 2008, 359:2767-2777.

3. Bowes J, Barton A: Recent advances in the genetics of RA susceptibility. Rheumatology (Oxford) 2008, 47:399-402.

4. Coenen MJ, Trynka G, Heskamp S, Franke B, van Diemen CC, Smolonska J, van Leeuwen M, Brouwer E, Boezen MH, Postma DS, Platteel M, Zanen P, Lammers JW, Groen HJ, Mali WP, Mulder CJ, Tack GJ, Verbeek WH, Wolters VM, Houwen RH, Mearin ML, van Heel DA, Radstake TR, van Riel PL, Wijmenga C, Barrera P, Zhernakova A: Common and different genetic background for rheumatoid arthritis and coeliac disease. Hum Mol Genet 2009, 18:4195-4203.

5. Martin $\mathrm{P}$, YEAR Consortium, BIRAC Consortium, Wilson AG, Morgan AW, Emery P, Steer S, Hocking $L$, Reid DM, Harrison P, Wordsworth P, Thomson W, Worthington J: Identification of AF4/FMR2 family, member 3 (AFF3) as a novel rheumatoid arthritis susceptibility locus and confirmation of two further pan-autoimmune susceptibility genes. Hum Mol Genet 2009, 18:2518-2522.

6. Barton A, Thomson W, Ke X, Eyre S, Hinks A, Bowes J, Plant D, Gibbons L, Wellcome Trust Case Control Consortium, YEAR Consortium, BIRAC Consortium, Wilson AG, Bax DE, Morgan AW, Emery P, Steer S, Hocking L, Reid DM, Wordsworth P, Harrison P, Worthington J: Rheumatoid arthritis susceptibility loci at chromosomes 10p15, $12 q 13$ and 22q13. Nat Genet 2008, 40:1156-1159.

7. Arnett FC, Edworthy SM, Bloch DA, MCShane DJ, Fries JF, Cooper NS, Healey LA, Kaplan SR, Liang MH, Luthra HS, et al: The American Rheumatism Association 1987 revised criteria for the classification of rheumatoid arthritis. Arthritis Rheum 1988, 31:315-324.

8. MacGregor AJ, Bamder S, Silman AJ: A comparison of the performance of different methods of disease classification for rheumatoid arthritis. Results from an analysis from a nationwide twin study. The Journal of Rheumatology 1994, 21:1420-1426.

9. Sequenom.com. [http://www.sequenom.com]

10. Hydra - USC - University of Southern California. [http://hydra.usc.edu/gxe/].

11. Raychaudhuri S, Thomson BP, Remmers EF, Eyre S, Hinks A, Guiducci C, Catanese JJ, Xie G, Stahl EA, Chen R, Alfredsson L, Amos Cl, Ardlie KG, BIRAC Consortium, Barton A, Bowes J, Burtt NP, Chang M, Coblyn J, Costenbader KH, Criswell LA, Crusius JB, Cui J, De Jager PL, Ding B, Emery P, Flynn E, Harrison P, Hocking $\sqcup$, Huizinga TW, et al: Genetic variants at CD28, PRDM1 and CD2/CD58 are associated with rheumatoid arthritis risk. Nat Genet 2009, 41:1313-1318.

12. Barrett JC, Clayton DG, Concannon P, Akolkar B, Cooper JD, Erlich HA, Julier C, Morahan G, Nerup J, Nierras C, Plagnol V, Pociot F, Schuilenburg H, Smyth DJ, Stevens H, Todd JA, Walker NM, Rich SS, The Type 1 Diabetes Genetics Consortium: Genome-wide association study and meta-analysis find that over 40 loci affect risk of type 1 diabetes. Nat Genet 2009, 41:703-707.

13. Dubois PC, Trynka G, Franke L, Hunt KA, Romanos J, Curtotti A, Zhernakova A, Heap GA, Adány R, Aromaa A, Bardella MT, van den Berg LH, Bockett NA, de la Concha EG, Dema B, Fehrmann RS, Fernández-Arquero M, Fiatal S, Grandone E, Green PM, Groen HJ, Gwilliam R, Houwen RH, Hunt SE, Kaukinen K, Kelleher D, Korponay-Szabo I, Kurppa K, MacMathuna P, Mäki M, et al: Multiple common variants for celiac disease influencing immune gene expression. Nat Genet 2010, 42:295-302.
14. Stahl EA, Raychaudhuri S, Remmers EF, Xie G, Eyre S, Thomson BP, Li Y, Kurreeman FA, Zhernakova A, Hinks A, Guiducci C, Chen R, Alfredsson L, Amos $\mathrm{Cl}$, Ardlie KG, BIRAC Consortium, Barton A, Bowes J, Brouwer E, Burtt NP, Catanese JJ, Coblyn J, Coenen MJ, Costenbader KH, Criswell LA, Crusius JB, Cui J, de Bakker PI, De Jager PL, Ding B, et al: Genome-wide association study meta-analysis identifies seven new rheumatoid arthritis risk loci. Nat Genet 2010, 42:508-514.

15. Kohem CL, Brenol JC, Xavier RM, Bredemeier M, Brenol CV, Dedavid e Silva TL, de Castilhos Mello A, Cañedo AD, Neves AG, Chies JA: The chemokine receptor CCR5 genetic polymorphism and expression in rheumatoid arthritis patients. Scand J Rheumatol 2007, 36:359-364.

16. Lindner E, Nordang GB, Melum E, Flatø B, Selvaag AM, Thorsby E, Kvien TK, Førre OT, Lie BA: Lack of association between the chemokine receptor 5 polymorphism CCR5delta32 in rheumatoid arthritis and juvenile idiopathic arthritis. BMC Med Genet 2007, 8:33.

17. Coenen MJ, Gregersen PK: Rheumatoid arthritis: a view of the current genetic landscape. Genes Immun 2009, 10:101-111.

18. Tomer $\mathrm{Y}$, Huber A: The etiology of autoimmune thyroid disease: A story of genes and environment. J Autoimmun 2009, 32:231-239.

19. Behrens EM, Finkel TH, Bradfield JP, Kim CE, Linton L, Casalunovo T, Frackelton EC, Santa E, Otieno FG, Glessner JT, Chiavacci RM, Grant SF, Hakonarson H: Association of the TRAF1-C5 locus on chromosome 9 with juvenile idiopathic arthritis. Arthritis Rheum 2008, 58:2206-2207.

20. Albers HM, Kurreeman FA, Houwing-Duistermaat JJ, Brinkman DM, Kamphuis SS, Girschick HJ, Wouters C, Van Rossum MA, Verduijn W, Toes RE, Huizinga TW, Schilham MW, ten Cate R: The TRAF1/C5 region is a risk factor for polyarthritis in juvenile idiopathic arthritis. Ann Rheum Dis 2008, 67:1578-1580.

doi:10.1186/ar3139

Cite this article as: Eyre et al:: Overlapping genetic susceptibility variants between three autoimmune disorders: rheumatoid arthritis, type 1 diabetes and coeliac disease. Arthritis Research \& Therapy 2010 12: R175.

\section{Submit your next manuscript to BioMed Central and take full advantage of:}

- Convenient online submission

- Thorough peer review

- No space constraints or color figure charges

- Immediate publication on acceptance

- Inclusion in PubMed, CAS, Scopus and Google Scholar

- Research which is freely available for redistribution 